\title{
Synthesis, Characterisation and Thermal Behaviour of Salicylates of Heterobimetallic [Ca(II)-Sn(IV)]- $\mu$-Oxoisopropoxide
}

\author{
RAJESH KUMAR ${ }^{1 *}$ and RAJVINDER KAUR ${ }^{2}$ \\ ${ }^{1}$ Department of Chemistry, HCTM Technical Campus, Kaithal -136027, India \\ ${ }^{2}$ Department of Chemistry, Singhania University, Pacheri Bari, \\ Jhunjhunu -333515, Rajasthan, India \\ dhullrajesh79@gmail.com
}

Received 3 June 2013 / Accepted 10 July 2013

\begin{abstract}
The heterobimetallic- $\mu$-oxoisopropoxide $\left[\mathrm{CaO}_{2} \mathrm{Sn}_{2}\left(\mathrm{OPr}^{\mathrm{i}}\right)_{6}\right]$ provides different salicylate derivatives of the type $\left[\mathrm{CaO}_{2} \mathrm{Sn}_{2}\left(\mathrm{OPr}^{\mathrm{i}}\right)_{6-\mathrm{n}}(\mathrm{RSAL})_{\mathrm{n}}\right]$ (where $\mathrm{n}$ is $1-4$ and $\mathrm{RSAL}=$ Salicylate anion) with methyl salicylate $\left(\mathrm{HRSAL}^{1}\right)$, ethyl salicylate $\left(\mathrm{HRSAL}^{2}\right)$ and phenyl salicylate $\left(\mathrm{HRSAL}^{3}\right)$. The derivatives have been characterized by elemental, spectral (IR, ${ }^{1} \mathrm{H},{ }^{13} \mathrm{C} N \mathrm{NR}$ ), thermal and molecular weight measurement. The hydrolyzed product of these salicylate derivatives obtained by hydrothermally assisted sol-gel process favors the formation of multicomponent oxides subject to their thermal study. The studies reveal that salicylate derivatives are monomeric in nature and low susceptible to hydrolysis in comparison to parent compound and may prove excellent precursors for the mixed metal oxides.
\end{abstract}

Keywords: Heterobimetallic- $\mu$-oxoisopropoxide, Calcium, Tin, Salicylates, Thermal analysis

\section{Introduction}

The investigation and the use of heterometallic alkoxides as single-source molecules precursors for synthesis of oxides have seen a rapid growth during the last more than one and half decade. The bimetallic oxo complexes, the true precursors play a significant role in the phase formation of complex oxides. The M-O-M bridges in bimetallic oxo complexes provide homogeneity of the newly formed oxide phases at the molecular level. The aboveconsidered peculiarity in the composition, stoichiometry, solubility and reactivity of orthoand oxoalkoxides are widely used in the sol-gel synthesis of a series of very important composites $^{1}$. The control of particle size and the morphology of the oxide are of crucial importance nowadays both from the fundamental and industrial point of view ${ }^{2}$. The multicomponent oxides synthesised as a result of sol-gel technique on heterometallic- $\mu$ oxoalkoxides $^{3-6}$ are found efficient to reduce the effect of harmful chemicals ${ }^{7}$ and decontaminating chemical warfare agents ${ }^{8-9}$. Nano-structured oxide, the new type of materials shows properties different from materials with $\mu \mathrm{m}$-scale microstructures are gaining more 
and more interests during the past few years. A variety of chemical routes have been developed to prepare ceramic nano-structures, because the traditional solid-state method could not meet particle size requirements and versatility of synthesis process. Some chemical methods offer possibly a preparation at lower temperatures, a homogenous primary structure and limited higher order aggregation and a small distribution of particle sizes. The $\mathrm{CaSnO}_{3}$ cubes exhibit high sensitivity, selectivity and reversibility to ethanol sensing due to a good combination of high specific surface areas, multi-composition and well-defined geometrics leading to selective surface activities of cubic shape $\mathrm{CaSnO}_{3}$ crystals ${ }^{10}$. Alkaline earth stannates have gained considerable attraction in recent years because of thermal stability in air and strong physical and chemical interaction with absorbed species. The materials have a variety of applications in ceramic dielectrics ${ }^{11,12}$, gas-sensing materials ${ }^{13}$ and battery electrode bodie ${ }^{\text {s14 }}$. The absorbed oxygen atom on the surface of the metal oxide, influences its electrical properties by producing an electron-depleted space-charge layer in the space-charge region of the species and makes the study more interested. Among the metal oxides, $\mathrm{SnO}_{2}$ acts as an important base material for gas sensing devices. Similarly, Calcium stannate in a pure and in doped form has been shown a gas sensing materials ${ }^{15-17}$. There are many articles about properties and behaviour of these type of materials, but no thoroughly and reliable studies are available on synthesis and thermodynamic stability of them in the $\mathrm{SnO}_{2}, \mathrm{CaSnO}_{3}$ and $\mathrm{Ca}_{2} \mathrm{SnO}_{4}$ configurations. Apart from their role as precursors for mixed metal oxides, the bimetallic- $\mu$-oxoalkoxides of transition metals have been found to rank among the excellent catalysts for the polymerization of heterocyclic monomers like lactones, oxiranes, thiiranes and epoxides.

In the present investigation, the derivatives of heterobimetallic [Ca(II)-Sn(IV)]- $\mu$ oxoisopropoxide are prepared from the condensation of $\left[\mathrm{CaO}_{2} \mathrm{Sn}_{2}\left(\mathrm{OPr}^{\mathrm{i}}\right)_{6}\right]$ with different salicylates in molar ratios (1:1-1:4) and the reaction proceeds with stepwise formation of salicylate derivatives of bimetallic [Ca(II)-Sn(IV)]- $\mu$-oxoisopropoxide, which are the molecular species that can be purified by distillation, allowing the isolation of pure molecular precursors.

\section{Experimental}

All the operations were carried out in dry nitrogen atmosphere using a vacuum line. Hydrocarbon solvents and reagents used were purified and dried by standard methods. The general technique and physical measurement were carried out as described elsewhere ${ }^{18-23}$. Hydrated calcium acetate (Aldrich) was made anhydrous with acetic anhydride and titanium isopropoxide $\left[\mathrm{Sn}\left(\mathrm{OPr}^{\mathrm{i}}\right)_{4}\right]$ (Aldrich) used without further purification. The methyl salicylate $\left(\mathrm{HRSAL}^{1}\right)$, ethyl salicylate $\left(\mathrm{HRSAL}^{2}\right)$, and phenyl salicylate $\left(\mathrm{HRSAL}^{3}\right)$ were prepared in laboratory and purified before use. The isopropoxy groups in the $\mu$-oxoisopropoxide and liberated isopropanol formed in preparation of Salicylate derivatives were estimated oxidimetrically. Calcium was determined complexometrically and gravimetric estimation has been done for titanium ${ }^{22}$. Titanium was estimated as $\mathrm{TiO}_{2}$ via the formation of titaniumphenazone complex ${ }^{22}$. Perkin-Elmer 1710 FTIR spectrometer over the range $4000-400 \mathrm{~cm}^{-1}$ used to record the Infrared spectra. The ${ }^{1} \mathrm{H},{ }^{13} \mathrm{C}$ NMR spectra were recorded in $\mathrm{CDCl}_{3}$ on Bruker Avance II 400 NMR spectrometer. TG study has been made on Diamond TG/DTA PerkinElmer instrument. Elemental analyses were carried out by PerkinElmer 2400 II series CHNS/O Analyzer.

\section{Synthesis of derivatives of $\left[\mathrm{CaO}_{2} \mathrm{Sn}_{2}\left(\mathrm{OPr}^{i}\right)_{6}\right]$ with salicylates}

The $[\mathrm{Ca}(\mathrm{II})-\mathrm{Sn}(\mathrm{IV})]-\mu$-oxoisopropoxide was synthesized by reported methods on thermal condensation of $\mathrm{Ca}(\mathrm{OAc})_{2}$ and $\mathrm{Sn}\left(\mathrm{OPr}^{\mathrm{i}}\right)_{4}$ in mixture of xylene and decalin in 1:2 molar ratio ${ }^{18-21}$. 


\section{Reaction of $\mu$-oxo compound with methyl salicylate in 1:1 molar ratio}

The $\left[\mathrm{CaO}_{2} \mathrm{Sn}_{2}\left(\mathrm{OPr}^{\mathrm{i}}\right)_{6}\right](0.666 \mathrm{~g}, 1.282 \mathrm{mmol})$ and methyl salicylate $(0.195 \mathrm{~g}, 1.282 \mathrm{mmol})$ were refluxed in benzene were refluxed in $\sim 50 \mathrm{~mL}$ benzene in a flask connected to a short distillation column on an oil bath for about $7 \mathrm{~h}$. The isopropanol liberated at $72-78{ }^{\circ} \mathrm{C}$ was fractionated as the binary azeotrope of isoproponol-benzene. The azeotrope was collected and checked for completion of the reaction. The excess of the solvent was then removed under reduced pressure yielding a yellowish semi-solid product. The syntheses of other Salicylate derivatives were carried out by similar procedure and the analytical results have been summarized in Table 1 .

Table 1. Analytical and physical data of studied compounds

\begin{tabular}{|c|c|c|c|c|c|c|c|c|c|c|}
\hline \multirow[b]{2}{*}{$\begin{array}{l}\dot{z} \\
\dot{s}\end{array}$} & \multirow[b]{2}{*}{$\begin{array}{c}\text { Compound } \\
\text { g mmol }\end{array}$} & \multirow{2}{*}{ 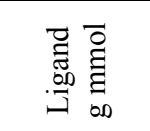 } & \multirow{2}{*}{ 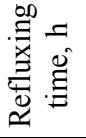 } & \multirow[b]{2}{*}{ Product, \% } & \multicolumn{6}{|c|}{ Anal. Found (Calcd.) } \\
\hline & & & & & $\mathrm{OPr}^{\mathrm{i}} \mathrm{g}$ & $\begin{array}{l}\mathrm{Ca} \\
\%\end{array}$ & $\mathrm{Sn} \%$ & $\mathrm{C} \%$ & $\mathrm{H} \%$ & $\mathrm{O} \%$ \\
\hline 1 & $\begin{array}{c}{\left[\mathrm{CaO}_{2} \mathrm{Sn}\right.} \\
\left.{ }_{2}\left(\mathrm{OPr}^{\mathrm{i}}\right)_{6}\right] \\
0.860 \\
(1.296)\end{array}$ & $\begin{array}{c}\text { HRSAL }^{1} \\
0.197 \\
(1.296)\end{array}$ & 8 & $\begin{array}{c}{\left[\mathrm{CaO}_{2} \mathrm{Sn}_{2}\left(\mathrm{OPr}^{\mathrm{i}}\right)_{5}\right.} \\
\left.\left(\mathrm{RSAL}^{1}\right)\right] \\
80.1\end{array}$ & $\begin{array}{c}0.05 \\
(0.06)\end{array}$ & $\begin{array}{c}5.21 \\
(5.29)\end{array}$ & $\begin{array}{c}31.44 \\
(31.48)\end{array}$ & $\begin{array}{c}37.95 \\
(38.09)\end{array}$ & $\begin{array}{c}5.51 \\
(5.55)\end{array}$ & $\begin{array}{c}19.01 \\
(19.04)\end{array}$ \\
\hline 2 & $\begin{array}{c}{\left[\mathrm{CaO}_{2} \mathrm{Sn}\right.} \\
\left.{ }_{2}\left(\mathrm{OPr}^{\mathrm{i}}\right)_{6}\right] \\
0.565 \\
(0.852)\end{array}$ & $\begin{array}{c}\text { HRSAL }^{1} \\
0.259 \\
(1.704)\end{array}$ & 10 & $\begin{array}{c}{\left[\mathrm{CaO}_{2} \mathrm{Sn}_{2}\left(\mathrm{OPr}^{\mathrm{i}}\right)_{4}\right.} \\
\left.\left(\mathrm{RSAL}^{1}\right)_{2}\right] \\
77.5\end{array}$ & $\begin{array}{c}0.08 \\
(0.09)\end{array}$ & $\begin{array}{c}4.78 \\
(4.71)\end{array}$ & $\begin{array}{c}28.14 \\
(28.06)\end{array}$ & $\begin{array}{c}42.42 \\
(42.45)\end{array}$ & $\begin{array}{c}4.93 \\
(4.95)\end{array}$ & $\begin{array}{c}22.65 \\
(22.64)\end{array}$ \\
\hline 3 & $\begin{array}{c}{\left[\mathrm{CaO}_{2} \mathrm{Sn}\right.} \\
\left.{ }_{2}\left(\mathrm{OPr}^{\mathrm{i}}\right)_{6}\right] \\
0.563 \\
(0.848)\end{array}$ & $\begin{array}{c}\text { HRSAL }^{1} \\
0.387 \\
(2.546)\end{array}$ & 12 & $\begin{array}{c}{\left[\mathrm{CaO}_{2} \mathrm{Sn}_{2}\left(\mathrm{OPri}^{\mathrm{i}}\right)_{3}\right.} \\
\left.\left(\mathrm{RSAL}^{1}\right)_{3}\right] \\
79.1\end{array}$ & $\begin{array}{c}0.09 \\
(0.11)\end{array}$ & $\begin{array}{c}4.22 \\
(4.25)\end{array}$ & $\begin{array}{c}25.22 \\
(25.31)\end{array}$ & $\begin{array}{c}45.87 \\
(45.95)\end{array}$ & $\begin{array}{c}5.47 \\
(4.46)\end{array}$ & $\begin{array}{c}25.32 \\
(25.53)\end{array}$ \\
\hline 4 & $\begin{array}{c}{\left[\mathrm{CaO}_{2} \mathrm{Sn}\right.} \\
\left.{ }_{2}\left(\mathrm{OPr}^{\mathrm{i}}\right)_{6}\right] \\
0.493 \\
(0.743)\end{array}$ & $\begin{array}{c}\text { HRSAL }^{1} \\
0.452(2.97 \\
3)\end{array}$ & 14 & $\begin{array}{c}{\left[\mathrm{CaO}_{2} \mathrm{Sn}_{2}\left(\mathrm{OPr}^{\mathrm{i}}\right)_{2}\right.} \\
\left.\left(\mathrm{RSAL}^{\mathrm{l}}\right)_{4}\right] \\
79.3\end{array}$ & $\begin{array}{c}0.13 \\
(0.15)\end{array}$ & $\begin{array}{c}3.71 \\
(3.87)\end{array}$ & $\begin{array}{c}23.19 \\
(23.06)\end{array}$ & $\begin{array}{c}48.89 \\
(48.83)\end{array}$ & $\begin{array}{c}4.07 \\
(4.07)\end{array}$ & $\begin{array}{l}27.78 \\
(27.9)\end{array}$ \\
\hline 5 & $\begin{array}{c}{\left[\mathrm{CaO}_{2} \mathrm{Sn}\right.} \\
\left.{ }_{2}\left(\mathrm{OPr}^{\mathrm{i}}\right)_{6}\right] \\
0.760 \\
(1.145)\end{array}$ & $\begin{array}{c}\text { HRSAL }^{2} \\
0.189 \\
(1.145)\end{array}$ & 8 & $\begin{array}{c}{\left[\mathrm{CaO}_{2} \mathrm{Sn}_{2}\left(\mathrm{OPr}^{\mathrm{i}}\right)_{5}\right.} \\
\left.\left(\mathrm{RSAL}^{2}\right)\right] \\
80.8\end{array}$ & $\begin{array}{c}0.08 \\
(0.09)\end{array}$ & $\begin{array}{l}5.14 \\
(5.2)\end{array}$ & $\begin{array}{c}30.87 \\
(30.94)\end{array}$ & $\begin{array}{c}39.12 \\
(39.01)\end{array}$ & $\begin{array}{c}5.75 \\
(5.72)\end{array}$ & $\begin{array}{c}18.85 \\
(18.72)\end{array}$ \\
\hline 6 & $\begin{array}{c}{\left[\mathrm{CaO}_{2} \mathrm{Sn}\right.} \\
\left.{ }_{2}\left(\mathrm{OPr}^{\mathrm{i}}\right)_{6}\right] \\
0.573 \\
(0.863)\end{array}$ & $\begin{array}{c}\text { HRSAL }^{2} \\
0.285 \\
(1.727)\end{array}$ & 10 & $\begin{array}{c}{\left[\mathrm{CaO}_{2} \mathrm{Sn}_{2}\left(\mathrm{OPr}^{\mathrm{i}}\right)_{4}\right.} \\
\left.\left(\mathrm{RSAL}^{2}\right)_{2}\right] \\
80.2\end{array}$ & $\begin{array}{c}0.06 \\
(0.06)\end{array}$ & $\begin{array}{c}4.44 \\
(4.57)\end{array}$ & $\begin{array}{c}27.21 \\
(27.23)\end{array}$ & $\begin{array}{c}43.91 \\
(43.93)\end{array}$ & $\begin{array}{c}5.22 \\
(5.26)\end{array}$ & $\begin{array}{c}21.98 \\
(21.96)\end{array}$ \\
\hline 7 & $\begin{array}{c}{\left[\mathrm{CaO}_{2} \mathrm{Sn}\right.} \\
\left.{ }_{2}\left(\mathrm{OPr}^{\mathrm{i}}\right)_{6}\right] \\
0.528 \\
(0.795)\end{array}$ & $\begin{array}{c}\text { HRSAL }^{2} \\
0.394 \\
(2.387)\end{array}$ & $12^{1 / 2}$ & $\begin{array}{c}{\left[\mathrm{CaO}_{2} \mathrm{Sn}_{2}\left(\mathrm{OPr}^{\mathrm{i}}\right)_{3}\right.} \\
\left.\left(\mathrm{RSAL}^{2}\right)_{3}\right] \\
78.8\end{array}$ & $\begin{array}{c}0.09 \\
(0.10)\end{array}$ & $\begin{array}{c}4.01 \\
(4.08)\end{array}$ & $\begin{array}{c}24.26 \\
(24.31)\end{array}$ & $\begin{array}{c}47.79 \\
(47.80)\end{array}$ & $\begin{array}{l}4.84 \\
(4.9)\end{array}$ & $\begin{array}{c}24.52 \\
(24.51)\end{array}$ \\
\hline 8 & $\begin{array}{c}{\left[\mathrm{CaO}_{2} \mathrm{Sn}\right.} \\
\left.{ }_{2}\left(\mathrm{OPr}^{\mathrm{i}}\right)_{6}\right] \\
0.480 \\
(0.724)\end{array}$ & $\begin{array}{c}\text { HRSAL }^{2} \\
0.478 \\
(2.896)\end{array}$ & 14 & $\begin{array}{c}{\left[\mathrm{CaO}_{2} \mathrm{Sn}_{2}\left(\mathrm{OPr}^{\mathrm{i}}\right)_{4}\right.} \\
\left.\left(\mathrm{RSAL}^{2}\right)_{4}\right] \\
79.4\end{array}$ & $\begin{array}{c}0.13 \\
(0.14)\end{array}$ & $\begin{array}{c}3.74 \\
(3.69)\end{array}$ & $\begin{array}{l}21.88 \\
(21.95)\end{array}$ & $\begin{array}{c}50.99 \\
(50.92)\end{array}$ & $\begin{array}{c}4.69 \\
(4.61)\end{array}$ & $\begin{array}{c}26.54 \\
(26.56)\end{array}$ \\
\hline 9 & $\begin{array}{c}{\left[\mathrm{CaO}_{2} \mathrm{Sn}\right.} \\
\left.{ }_{2}\left(\mathrm{OPr}^{\mathrm{i}}\right)_{6}\right] \\
0.580 \\
(0.873)\end{array}$ & $\begin{array}{c}\text { HRSAL }^{3} \\
0.187 \\
(0.873)\end{array}$ & 8 & $\begin{array}{c}{\left[\mathrm{CaO}_{2} \mathrm{Sn}_{2}\left(\mathrm{OPr}^{\mathrm{i}}\right)_{5}\right.} \\
\left.\left(\mathrm{RSAL}^{3}\right)\right] \\
81.5\end{array}$ & $\begin{array}{c}0.03 \\
(0.04)\end{array}$ & $\begin{array}{c}4.77 \\
(4.89)\end{array}$ & $\begin{array}{c}29.79 \\
(29.89)\end{array}$ & $\begin{array}{c}42.59 \\
(42.54)\end{array}$ & $\begin{array}{c}5.38 \\
(5.37)\end{array}$ & $\begin{array}{l}17.57 \\
(17.6)\end{array}$ \\
\hline
\end{tabular}




\begin{tabular}{|c|c|c|c|c|c|c|c|c|c|c|}
\hline 10 & $\begin{array}{c}{\left[\mathrm{CaO}_{2} \mathrm{Sn}_{2}\right.} \\
\left.\left(\mathrm{OPr}^{\mathrm{i}}\right)_{6}\right] \\
0.442 \\
(0.666)\end{array}$ & $\begin{array}{c}\text { HRSAL }^{3} \\
0.285 \\
(1.331)\end{array}$ & $10^{1 / 2}$ & $\begin{array}{c}{\left[\mathrm{CaO}_{2} \mathrm{Sn}_{2}\left(\mathrm{OPr}^{\mathrm{i}}\right)_{4}\right.} \\
\left.\left(\mathrm{RSAL}^{3}\right)_{2}\right] \\
80.5\end{array}$ & $\begin{array}{c}0.06 \\
(0.07)\end{array}$ & $\begin{array}{c}4.16 \\
(4.11)\end{array}$ & $\begin{array}{c}24.39 \\
(24.48)\end{array}$ & $\begin{array}{c}49.27 \\
(49.38)\end{array}$ & $\begin{array}{c}4.68 \\
(4.73)\end{array}$ & $\begin{array}{c}19.78 \\
(19.75)\end{array}$ \\
\hline 11 & $\begin{array}{c}{\left[\mathrm{CaO}_{2} \mathrm{Sn}_{2}\right.} \\
\left.\left(\mathrm{OPr}^{\mathrm{i}}\right)_{6}\right] \\
0.426 \\
(0.641)\end{array}$ & $\begin{array}{c}\text { HRSAL }^{3} \\
0.412 \\
(1.925)\end{array}$ & $12^{1 / 2}$ & $\begin{array}{c}{\left[\mathrm{CaO}_{2} \mathrm{Sn}_{2}\left(\mathrm{OPr}^{\mathrm{i}}\right)_{3}(\right.} \\
\left.\left.\mathrm{RSAL}^{3}\right)_{3}\right] \\
80.2\end{array}$ & $\begin{array}{c}0.08 \\
(0.10)\end{array}$ & $\begin{array}{c}3.52 \\
(3.55)\end{array}$ & $\begin{array}{c}21.08 \\
(21.13)\end{array}$ & $\begin{array}{c}54.55 \\
(54.59)\end{array}$ & $\begin{array}{c}4.22 \\
(4.26)\end{array}$ & $\begin{array}{c}21.35 \\
(21.31)\end{array}$ \\
\hline 12 & $\begin{array}{c}{\left[\mathrm{CaO}_{2} \mathrm{Sn}_{2}\right.} \\
\left.\left(\mathrm{OPr}^{\mathrm{i}}\right)_{6}\right] \\
0.401 \\
(0.604)\end{array}$ & $\begin{array}{c}\text { HRSAL }^{3} \\
0.517 \\
(2.416)\end{array}$ & 14 & $\begin{array}{c}{\left[\mathrm{CaO}_{2} \mathrm{Sn}_{2}\left(\mathrm{OPr}^{\mathrm{i}}\right)_{2}(\right.} \\
\left.\left.\mathrm{RSAL}^{3}\right)_{4}\right] \\
78.4\end{array}$ & $\begin{array}{c}0.12 \\
(0.13)\end{array}$ & $\begin{array}{c}3.09 \\
(3.12)\end{array}$ & $\begin{array}{c}18.55 \\
(18.59)\end{array}$ & $\begin{array}{c}58.17 \\
(58.12)\end{array}$ & $\begin{array}{l}3.88 \\
(3.9)\end{array}$ & $\begin{array}{l}22.41 \\
(22.5)\end{array}$ \\
\hline
\end{tabular}

The hydrolyzed product of salicylates of $\mu$-oxo compound obtained by hydrothermally assisted sol-gel processing. For the hydrothermally assisted sol-gel processing, salicylate derivatives were diluted 20 times by weight with isopropanol, the mixture was loaded into a glass container and transferred into a $300 \mathrm{~mL}$ stainless steel autoclave. Dilution of salicylate derivatives and their transfer into autoclave was performed in moisture-free atmosphere to prevent their hydrolysis before introducing into a hydrothermal chamber. The gap between glass container and chamber was filled with $40 \mathrm{ml}$ of distilled water and then the autoclave was tightly closed. The chamber was heated $120^{\circ} \mathrm{C}$ for five hours, the autoclave was cooled and the product was filtered off and dried overnight at $100^{\circ} \mathrm{C}$.

\section{Results and Discussion}

Many reactions of $[\mathrm{Ca}(\mathrm{II})-\mathrm{Sn}(\mathrm{IV})]-\mu$-oxoisopropoxide with bidentate salicylates (HRSAL) i.e. methyl salicylate $\left(\mathrm{HRSAL}^{1}\right)$, ethyl salicylate $\left(\mathrm{HRSAL}^{2}\right)$, phenyl salicylate $\left(\mathrm{HRSAL}^{3}\right)$ are performed in different molar ratios in refluxing benzene, yielding the products of type $\left[\mathrm{CaO}_{2} \mathrm{Sn}_{2}\left(\mathrm{OPr}^{\mathrm{i}}\right)_{5}(\mathrm{RSAL})\right],\left[\mathrm{CaO}_{2} \mathrm{Sn}_{2}\left(\mathrm{OPr}^{\mathrm{i}}\right)_{4}(\mathrm{RSAL})_{2}\right],\left[\mathrm{CaO}_{2} \mathrm{Sn}_{2}\left(\mathrm{OPr}^{\mathrm{i}}\right)_{3}(\mathrm{RSAL})_{3}\right]$ and $\left[\mathrm{CaO}_{2} \mathrm{Sn}_{2}\right.$ $\left.\left(\mathrm{OPr}^{\mathrm{i}}\right)_{2}(\mathrm{RSAL})_{4}\right]$. The preparation of the salicylate derivatives of $\left[\mathrm{CaO}_{2} \mathrm{Sn}_{2}\left(\mathrm{OPr}^{\mathrm{i}}\right)_{6}\right]$ follows the following reaction scheme 1 :

$$
\begin{aligned}
& {\left[\mathrm{CaO}_{2} \mathrm{Sn}_{2}\left(\mathrm{OPr}^{\mathrm{i}}\right)_{6}\right]+\text { nHRSAL refluxing benzene } \underset{\longrightarrow}{\longrightarrow}\left[\mathrm{CaO}_{2} \mathrm{Sn}_{2}\left(\mathrm{OPr}^{\mathrm{i}}\right)_{6-\mathrm{n}}(\mathrm{RSAL})_{\mathrm{n}}\right]+\mathrm{nPr}^{\mathrm{i} O H}} \\
& (\mathrm{n}=1-4, \mathrm{HRSAL}=\text { methyl/ethyl/phenyl Salicylate })
\end{aligned}
$$

\section{Scheme 1}

The salicylate derivatives are susceptible to hydrolysis and soluble in common organic solvents such as benzene, chloroform and carbon tetrachloride etc. The isopropanol liberated during the course of the reaction was collected azeotropically (isopropanol-benzene) and estimated oxidimetrically to check the progress of the reaction. It was observed that only four out of the six isopropoxy groups of $[\mathrm{Ca}(\mathrm{II})-\mathrm{Sn}(\mathrm{IV})]-\mu$-oxoisopropoxide could be replaced by salicylates. Futher replacement of isopropoxy groups could not be achieved even with an excess of ligand (salicylates) and prolonged refluxing time $(26 \mathrm{~h})$. This indicates the non-replacement of bridging isopropoxy groups and that only terminal isopropoxy groups are substituted by salicylates.

\section{Spectral Analysis of salicylate derivatives of $\left[\mathrm{CaO}_{2} \mathrm{Sn}_{2}\left(\mathrm{OPr}^{\mathrm{i}}\right)_{6}\right]$}

\section{IR spectra}

The complete disappearance of a broad band in the region $3000-2700 \mathrm{~cm}^{-1}$ due to $v(\mathrm{O}-\mathrm{H})$, in all $\mu$-oxo salicylate deivatives indicates the deprotonation of these ligands. The downward shift of $15-25 \mathrm{~cm}^{-1}$ in $v(\mathrm{C}-\mathrm{O})$ band appearing at $\sim 1645 \mathrm{~cm}^{-1}$ in salicylate derivatives are indicating 
the coordination of the carbonyl oxygen of the salicylates to the metal atom. A strong band observed at $\sim 1240 \mathrm{~cm}^{-1}$ in salicylates due to phenolic $v(\mathrm{C}-\mathrm{O})$ vibrations is shifted $10-20 \mathrm{~cm}^{-1}$ higher in the derivatives indicating bond formation of phenolic oxygen of salicylate to the metal atom. All the derivatives show an absorption band in the region $1360-1340 \mathrm{~cm}^{-1}$ is characteristic of gem-dimethyl of the isopropoxy group. The bands observed at about 1160 and $1120 \mathrm{~cm}^{-1}$ in 1:3 salicylate derivatives of $\left[\mathrm{CaO}_{2} \mathrm{Sn}_{2}\left(\mathrm{OPr}^{\mathrm{i}}\right)_{6}\right]$ have been assigned to combination bands $v\left(\mathrm{C}-\mathrm{O}+\mathrm{Opr}^{\mathrm{i}}\right)$ non-bridging and $v\left(\mathrm{C}-\mathrm{O}+\mathrm{Opr}^{\mathrm{i}}\right)$ bridging of the isopropoxy groups respectively ${ }^{24}$. However, the band at $\sim 1160 \mathrm{~cm}^{-1}$ due to $v\left(\mathrm{C}-\mathrm{O}+\mathrm{Opr}^{\mathrm{i}}\right)$ terminal is absent in $1: 4$ salicylate derivatives suggests the presence of bridging isopropoxy groups only. The vibration occurring at $\sim 940 \mathrm{~cm}^{-1}$ in all the derivatives has been assigned to $v(\mathrm{C}-\mathrm{O})$ of the bridging isopropoxy group. A number of bands appearing in the region $700-400 \mathrm{~cm}^{-1}$ are due to $\mathrm{M}-\mathrm{O}$ stretching vibrations in these derivatives ${ }^{25-26}$. The bands related to phenyl groups in the salicylate derivatives are observed at their usual positions in the IR spectra as observed in the ligands ${ }^{26}$. The IR spectra of the derivatives indicate that salicylates behave as monobasic bidentate ligands.

\section{NMR spectra}

${ }^{1} \mathrm{H}$ NMR spectra of all the salicylate derivatives of $\left[\mathrm{CaO}_{2} \mathrm{Sn}_{2}\left(\mathrm{Opr}^{\mathrm{i}}\right)_{6}\right]$ show broad multiplet centered between $\delta 0.8-1.2 \mathrm{ppm}$ due to the intermixing of methyl protons of isopropoxy groups. A broad multiplet centered at $\delta$ 4.1-4.4 observed due to the ethane proton of isopropoxy groups in the spectra of all derivatives. Very similar spectra obtained for compounds formed by reactions of 1:5 and 1:6 molar ratios of $\mu$-oxo compound and salicylates as of 1:4 salicylate derivatives of $\mu$-oxoisopropoxide. This confirms the nonreplacement of bridging isopropoxy groups by salicylates.

The ${ }^{1} \mathrm{H}$ NMR spectra of salicylates show a broad singlet at $\sim \delta 12.9 \mathrm{ppm}$ due to phenolic $\mathrm{O}-\mathrm{H}$ proton, the absence this peak in the derivatives confirms their deprotonation. The peak at $\sim \delta 3.9 \mathrm{ppm}$ due to methyl protons of methyl salicylate and ethane proton of the ethyl salicylate is found to overlap with the multiplet centered at $\delta 4.2 \mathrm{ppm}$ due to ethane protons of the isopropoxy group in the derivatives of $\left[\mathrm{CaO}_{2} \mathrm{Sn}_{2}\left(\mathrm{Opr}^{\mathrm{i}}\right)_{6}\right]$. A broad doublet centered at $\sim \delta 1.2 \mathrm{ppm}$ is observed in mono to tri derivatives is due to the methyl protons of different types of isopropoxy groups (terminal and intramolecularly bridged). However, a fairly sharp doublet at $\delta 1.1 \mathrm{ppm}$ is observed in methyl and phenyl salicylate tetra derivatives indicate the presence of only one type of isopropoxy group/s (probably bridging). In case of ethyl salicylate derivatives the methyl protons are mixed with the methyl protons of the isopropoxy group resulting in a broad peak centered at $\delta 1.1 \mathrm{ppm}$. The signals due to phenyl ring protons of salicylate moiety are observed at their usual positions $(\delta 6.4-\delta 7.6 \mathrm{ppm})$ in all the derivatives.

The ${ }^{13} \mathrm{C}$ NMR spectra mono derivatives of $\left[\mathrm{CaO}_{2} \mathrm{Sn}_{2}\left(\mathrm{Opr}^{\mathrm{i}}\right)_{6}\right]$ shows two prominent peaks at $\delta 26.3-26.7$ and $\delta 28.1 .28 .9 \mathrm{ppm}$ assignable to the methyl carbon of terminal and interamolecularly bridged isopropoxy moiety and two different type of ethane carbons of isopropoxy group is confirmed by the two signals observed at $\delta 62.6-62.9 \mathrm{ppm}$ and $\delta \sim 63.4$ $64.2 \mathrm{ppm}^{27}$. The spectra of 1:4 salicylate derivatives of $\mu$-oxoisopropoxide show the absence of terminal isopropoxy group. All signals of $\left[\mathrm{CaO}_{2} \mathrm{Sn}_{2}\left(\mathrm{Opr}^{\mathrm{i}}\right)_{2}(\mathrm{RSAL})_{4}\right]$ are experiential in the spectra taken for compounds formed by reactions of 1:5 and 1:6 molar ratios of $\mu$-oxo compound and salicylates confirms the non-replacement of bridging isopropoxy groups by salicylates. The peaks observed in the region $\delta 128.8-141.3 \mathrm{ppm}$ are due to carbon atoms on benzene ring, however, the peak observed at about $\delta 163.8-169.9 \mathrm{ppm}$ is due to ring carbon linked to the ester group and a peak observed at $\delta 175.3-182.7 \mathrm{ppm}$ is due to carbon of the ester group (-COOR) $)^{27}$. 


\section{Thermal studies}

The thermal decomposition of salicylate derivatives of $\left[\mathrm{CaO}_{2} \mathrm{Sn}\left(\mathrm{OPr}^{\mathrm{i}}\right)_{4}\right]$ have been examined by thermogravimetric analysis under a flow of dry nitrogen, up to $800{ }^{\circ} \mathrm{C}$ at a heating rate of $10{ }^{\circ} \mathrm{C} / \mathrm{min}$. The minor weight loss $(1.77-2.12 \%)$ starts at $55.5-59.8{ }^{\circ} \mathrm{C}$ and completed at $184.8-188.5^{\circ} \mathrm{C}$ with a weight loss of due to presence of moisture and fraction of solvent present, if any. The second and major one starts at $1884.8-188.5^{\circ} \mathrm{C}$ and is completed at $359-$ $363{ }^{\circ} \mathrm{C}$, resulting in a residue amounting to $12.247-13.857 \%$ of the initial weight, probably due to the decomposition of partially hydrolyzed $\mu$-oxo salicylate into metal/mixed metal oxides suggesting the volatile nature of compound ${ }^{28}$.

The thermogravimetric analysis of various hydrolyzed product of different salicylate derivatives have been performed up to $800{ }^{\circ} \mathrm{C}$ at $10{ }^{\circ} \mathrm{C} / \mathrm{min}$. Thermograms of various hydrolysed salicylate derivatives studied as, the weight loss in stage (a) observed due to the traces of water and solvent present in hydrolyzed product of $\mu$-oxo compound. The major weight loss in stage (b) occurs probably due to the elimination of hydroxy groups and organic moieties present in the hydrolyzed product which is directly followed by last stage (c) ranging from $345-359{ }^{\circ} \mathrm{C}$ to $800{ }^{\circ} \mathrm{C}$, leaving a residue that is less than the calculated for mixed metal oxide and metal oxides $\left(\mathrm{CaSnO}_{3}\right.$ and $\left.\mathrm{SnO}_{2}\right)$. The detailed study of thermograms of hydrolyzed product of various salicylate derivatives is summarized in Table 2. The molecular weight measurement carried out in dry benzene using cryoscopic method suggests monomeric nature of salicylate derivatives.

Table 2. Study of thermograms of hydrolyzed product of various salicylate derivatives of $\left[\mathrm{CaO}_{2} \mathrm{Sn}\left(\mathrm{OPr}^{\mathrm{i}}\right)_{4}\right]$

\begin{tabular}{|c|c|c|c|}
\hline S. No. & Compound & Temperature range, ${ }^{\circ} \mathrm{C}$ & Weight loss, $\%$ \\
\hline 1. & {$\left[\mathrm{CaO}_{2} \mathrm{Sn}_{2}\left(\mathrm{OPr}^{\mathrm{i}}\right)_{5}\left(\mathrm{RSAL}^{1}\right)\right]$} & $\begin{array}{l}\text { (a) } 54-215 \text {, (b) } 215-350 \\
\text { (c) }>350\end{array}$ & $\begin{array}{l}\text { (a) 6, (b) } 47.84 \\
\text { (c) No significant loss }\end{array}$ \\
\hline 2. & {$\left[\mathrm{CaO}_{2} \mathrm{Sn}_{2}\left(\mathrm{OPr}^{\mathrm{i}}\right)_{4}\left(\mathrm{RSAL}^{1}\right)_{2}\right]$} & $\begin{array}{l}\text { (a) } 54-218 \text {, (b) } 218-354 \\
\text { (c) }>354\end{array}$ & $\begin{array}{l}\text { (a) } 5 \text {, (b) } 54.17 \\
\text { (c) No significant loss }\end{array}$ \\
\hline 3. & {$\left[\mathrm{CaO}_{2} \mathrm{Sn}_{2}\left(\mathrm{OPr}^{\mathrm{i}}\right)_{3}\left(\mathrm{RSAL}^{2}\right)_{3}\right]$} & $\begin{array}{l}\text { (a) } 56-220 \text {, (b) } 220-356 \\
\text { (c) }>356\end{array}$ & $\begin{array}{l}\text { (a) } 5 \text {, (b) } 58.36 \\
\text { (c) No Significant loss }\end{array}$ \\
\hline 4. & {$\left[\mathrm{CaO}_{2} \mathrm{Sn}_{2}\left(\mathrm{OPr}^{\mathrm{i}}\right)_{2}\left(\mathrm{RSAL}^{2}\right)_{4}\right]$} & $\begin{array}{l}\text { (a) } 55-225 \text {, (b) } 225-358 \\
\text { (c) }>358\end{array}$ & $\begin{array}{l}\text { (a) } 4 \text {, (b) } 62.51 \\
\text { (c) No significant loss }\end{array}$ \\
\hline 5. & {$\left[\mathrm{CaO}_{2} \mathrm{Sn}_{2}\left(\mathrm{OPr}^{\mathrm{i}}\right)_{5}\left(\mathrm{RSAL}^{3}\right)\right]$} & $\begin{array}{l}\text { (a) } 59-228 \text {, (b) } 228-356 \\
\text { (c) }>349\end{array}$ & $\begin{array}{l}\text { (a) } 5 \text {, (b) } 49.85 \\
\text { (c) No significant loss }\end{array}$ \\
\hline 6. & {$\left[\mathrm{CaO}_{2} \mathrm{Sn}_{2}\left(\mathrm{OPr}^{\mathrm{i}}\right)_{4}\left(\mathrm{RSAL}^{3}\right)_{2}\right]$} & $\begin{array}{l}\text { (a) } 58-225 \text {, (b) } 225-352 \\
\text { (c) }>352\end{array}$ & $\begin{array}{l}\text { (a) } 6, \text { (b) } 54.84 \\
\text { (c) No significant loss }\end{array}$ \\
\hline 7. & {$\left[\mathrm{CaO}_{2} \mathrm{Sn}_{2}\left(\mathrm{OPr}^{\mathrm{i}}\right)_{3}\left(\mathrm{RSAL}^{4}\right)_{3}\right]$} & $\begin{array}{l}\text { (a) } 53-227 \text {, (b) } 227-355 \\
\text { (c) }>355\end{array}$ & $\begin{array}{l}\text { (a) } 4 \text {, (b) } 61.25 \\
\text { (c) No significant loss }\end{array}$ \\
\hline 8. & {$\left[\mathrm{CaO}_{2} \mathrm{Sn}_{2}\left(\mathrm{OPr}^{\mathrm{i}}\right)_{2}\left(\mathrm{RSAL}^{4}\right)_{4}\right]$} & $\begin{array}{l}\text { (a) } 61-230, \text { (b) } 230-358 \\
\text { (c) }>358\end{array}$ & $\begin{array}{l}\text { (a) } 5 \text {, (b) } 62.41 \\
\text { (c) No significant loss }\end{array}$ \\
\hline 9. & {$\left[\mathrm{CaO}_{2} \mathrm{Sn}_{2}\left(\mathrm{OPr}^{\mathrm{i}}\right)_{5}\left(\mathrm{RSAL}^{1}\right)\right]$} & $\begin{array}{l}\text { (a) } 53-222 \text {, (b) } 222-350 \\
\text { (c) }>350\end{array}$ & $\begin{array}{l}\text { (a) } 5 \text {, (b) } 53.08 \\
\text { (c) No significant loss }\end{array}$ \\
\hline 10. & {$\left[\mathrm{CaO}_{2} \mathrm{Sn}_{2}\left(\mathrm{OPr}^{\mathrm{i}}\right)_{4}\left(\mathrm{RSAL}^{1}\right)_{2}\right]$} & $\begin{array}{l}\text { (a) } 58-227, \text { (b) } 227-355 \\
\text { (c) }>355\end{array}$ & $\begin{array}{l}\text { (a) } 6 \text {, (b) } 58.48 \\
\text { (c) No significant loss }\end{array}$ \\
\hline 11. & {$\left[\mathrm{CaO}_{2} \mathrm{Sn}_{2}\left(\mathrm{OPr}^{\mathrm{i}}\right)_{3}\left(\mathrm{RSAL}^{2}\right)_{3}\right]$} & $\begin{array}{l}\text { (a) } 58-228 \text {, (b) } 228-356 \\
\text { (c) }>356\end{array}$ & $\begin{array}{l}\text { (a) } 4 \text {, (b) } 65.42 \\
\text { (c) No Significant loss }\end{array}$ \\
\hline 12. & {$\left[\mathrm{CaO}_{2} \mathrm{Sn}_{2}\left(\mathrm{OPr}^{\mathrm{i}}\right)_{4}\left(\mathrm{RSAL}^{2}\right)_{2}\right]$} & $\begin{array}{l}\text { (a) } 61-239 \text {, (b) } 239-345 \\
\text { (c) }>345\end{array}$ & $\begin{array}{l}\text { (a) } 5 \text {, (b) } 68.22 \\
\text { (c) No significant loss }\end{array}$ \\
\hline
\end{tabular}




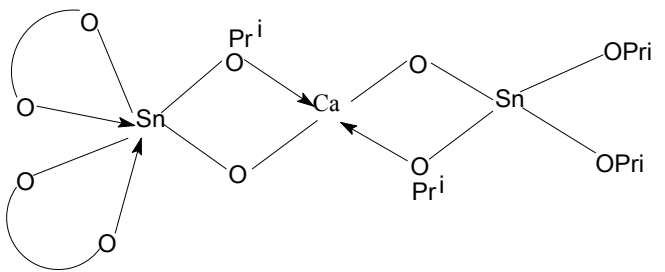

Figure 1. Suggested structure of $\left[\mathrm{CaO}_{2} \mathrm{Sn}_{2}\left(\mathrm{OPr}^{\mathrm{i}}\right)_{4}(\mathrm{RSAL})_{2}\right]$

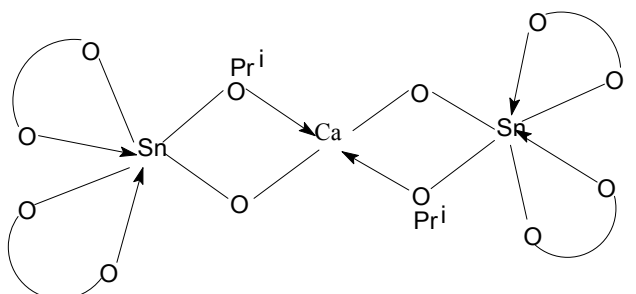

Figure 2. Suggested structure of $\left[\mathrm{CaO}_{2} \mathrm{Sn}_{2}\left(\mathrm{OPr}^{\mathrm{i}}\right)_{2}(\mathrm{RSAL})_{4}\right]$

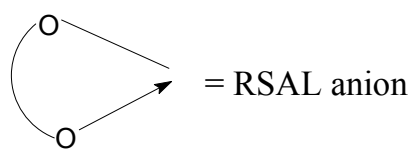

\section{Conclusion}

The aforementioned studies reveals the suggestive structures of salicylate derivatives of oxo complex of the type $\left[\mathrm{CaO}_{2} \mathrm{Sn}_{2}\left(\mathrm{OPr}^{\mathrm{i}}\right)_{5}(\mathrm{RSAL})\right],\left[\mathrm{CaO}_{2} \mathrm{Sn}_{2}\left(\mathrm{OPr}^{\mathrm{i}}\right)_{4}(\mathrm{RSAL})_{2}\right],\left[\mathrm{CaO}_{2} \mathrm{Sn}_{2}\left(\mathrm{OPr}^{\mathrm{i}}\right)_{3}\right.$ $\left.(\mathrm{RSAL})_{3}\right]$ and $\left[\mathrm{CaO}_{2} \mathrm{Sn}_{2}\left(\mathrm{OPr}^{\mathrm{i}}\right)_{2}(\mathrm{RSAL})_{4}\right]$. TGA study reveals the volatile nature of derivatives and their hydrolysed product may fabricate the mixed metal oxides. The proposed structures double and terta derivatives are given in Figure 1 and Figure 2 respectively.

\section{Acknowledgement}

Sincere thanks are due to Haryana College of Technology and Management Technical Campus, Kaithal for providing the necessary facilities to the author.

\section{References}

1. Turova N Ya, Russian Chem Rev., 2004, 73(11), 1041-1064.

2. Vayssieres L, Hagfeldt A and Lindquist S E, Pure Appl Chem., 2000, 72(1-2), 47-52; DOI:10.1351/pac200072010047

3. Kapoor P N, Bhagi A K, Mulukutla R S and Klabunde K J Dekker, Encyclopedia of Nanoscience and Nanotechnology; Marcel Deker; NewYork, 2004, 2007.

4. Kapoor P N, Sharma H K, Bhagi A K and Sharma M, J Indian Chem Soc., 2004, 81, 273-281.

5. Mohammadnezhad G, Amini M M and Khavasi H R, Dalton Trans., 2010, 39, 10830-10832; DOI:10.1039/C0DT00983K

6. Hubert-Pfalzgraf L G and Daniele S, Comptes Rendus Chimie, 2004, 7(5), 521-527; DOI:10.1016/j.crci.2004.03.001 
7. Carnes C L, Kapoor P N, Klabunde K J and Bonevich J, Chem Mater., 2002, 14, 2922-2929; DOI:10.1021/cm011590i

8. Wagner G W, Procell L R, O'Connor R J, Munavalli S, Carnes C L, Kapoor P N and Klabunde K J, J Am Chem Soc., 2001, 123, 1636-1644; DOI:10.1021/ja003518b

9. Medine G M, Zaikovskii V and Klabunde K J, J Mater Chem., 2004, 14, 757-763; DOI:10.1039/B313032K

10. Cheng H and Zhouguang Lu, Solid State Science, 2008, 10(8), 1042-1048; DOI:10.1016/j.solidstatesciences.2007.11

11. Zhouguang Lu, Junfeng Liu, Yougen Tang and Yadong Li, Inorg Chem Commun., 2004, 7(6), 731-733; DOI:10.1016/j.inoche.2004.03.030

12. Buchanan R C, Ceramic Materials for Electronic Applications; Marcel Dekker: New York, 1986, 69.

13. Feng Li, Liying Chen, Zhiqiang Chen, Jiaqiang $\mathrm{Xu}$, Jianmin Zhu and Xinquan Xin Mater Chem Phys., 2002, 73(2-3), 335-338; DOI:10.1016/S0254-0584(01)00357-1

14. Sharma N, Shaju K M, Subba Rao G V and Chowdari B V R, Electrochem Commun., 2002, 4(12), 947-952; DOI:10.1016/S1388-2481(02)00495-2

15. Tao S, Gao F, Liu X and Sorensen O T, Sensors Actuators B: Chem., 2000, 71(3), 223-227; DOI:10.1016/S0925-4005(00)00618-3

16. Azad A M, Lucia L Woan S and Pang T Y, J Alloys Comp., 1999, 282(1-2), 109-124; DOI:10.1016/S0925-8388(98)00808-1

17. He Z Q, Li X H, Liu E H, Hou Z H, Deng L F and Chuen Y H, J Cent Sout Univ., 2003, 10(3), 195-197; DOI:10.1007/s11771-003-0007-9.

18. Sharma H K and Kapoor P N, Polyhedron, 1988, 7(15), 1389-1391; DOI:10.1016/S0277-5387(00)80390-3

19. Kumar R, J Chem., 2012, 9(3), 1058-1063; DOI:10.1155/2012/450821

20. Kumar R and Sharma H K, J Korean Chem Soc., 2012, 56(1), 54.

21. Sharma H K and Kumar R, Indian J Chem., 2008, 47A, 854-858.

22. Vogel A I, A Text Book of Quantitative analysis; Longman: London, 1989.

23. Armarego W L F and Perrin D R, Purification of Laboratory Chemicals; $4^{\text {th }}$ Edn., Oxford: Boston: Butterworth Heinemann, 1997

24. Osipov O A, Minkin Verknovodova V I and Knyazhanskii M I, Zh Neorg Khim., 1967, 12, 1549.

25. Bradley D C, Halim F M A and Wardlaw W, J Chem Soc., 1950, 3450-3454; DOI:10.1039/JR9500003450

26. Nakamoto K, Infrared and Raman Spectra of Inorganic and Coordination Compounds; John Wiley and Sons: New York, 1986.

27. Brcitmair E and Voelter W, ${ }^{13} \mathrm{C}$ NMR spectroscopy (High Resolution Methods and Application in Organic Chemistry and Biochemistry); VCH: New York, 1990.

28. Mirzaee M, Amini M M, Sadeghi M, Mousavi F Y and Sharbatdaran M, Ceram Silikáty., 2005, 49(1), 40-47. 